\title{
The structure of a group of adult disabled patients treated dentally under general anesthesia
}

\begin{abstract}
Introduction. Adult disabled people, including mentally handicapped ones, constitute a very serious medical problem in both general and specialist medical care, including dentistry. Dental treatment under general anesthesia is the most recommended for this group of patients.

Aim. The aim of this study was to analyze the structure of a group of adult disabled patients treated dentally under general anesthesia.

Material and methods. The study was conducted among 147 disabled people, 61 females and 86 males aged 18-56 (the average age - 26.69) from the Lubelskie Voivodeship, qualified for dental treatment under general anesthesia . The survey was basedon interviews with the family members or social workers. The questionnaire included the information concerning general diseases, age, gender, place of residence and the kind of care (family or social welfare institutions). Special attention was paid to the previous dental treatment performed in outpatient clinics or under general anesthesia.

Results. The study involved a group of 147 people, including $58.50 \%$ males and $41.50 \%$ females. The average age of the patients was $26.69 \pm 6.41$ years (ranged from 18 to 56 ). The patients from a big city accounted for $40.14 \%, 23.13 \%$ of the subjects came from a small town, and $36.73 \%$ of the people came from the village. The largest group of patients included people with mental disabilities $-54.43 \%$. Most people $(87.76 \%)$ lived with their family, while $12.24 \%$ were the residents of social welfare institutions. The analysis of the data reveals that for $89.80 \%$ of patients, it was their first dental treatment under general anesthesia, and for $10.20 \%$, a subsequent one. Studies have shown that early treatment in outpatient clinics wasperformed in only $27.21 \%$ of treated people, while $72.79 \%$ have never been treated in a dental surgery.

Conclusions. Mentally handicapped people were the largest group of patients treated dentally under general anesthesia. Patients living in the urban areas and under the care of families were more often treated dentally under general anesthesia. Because of the lack of cooperation between disabled patients and the dentist, the complete dental treatment under general anesthesia is the most effective therapy. Adult disabled patients require special dental care.
\end{abstract}

Keywords: The adult disabled patients, dental treatment, general anesthesia.

DOI: $10.2478 /$ pjph-2014-0029

\section{INTRODUCTION}

Disability, despite its causes, is a serious social problem and one of the most important aspects of the evaluation of the human health condition. Although there have been many legal attempts to improve the availability of medical care for the population of the disabled, numerous barriers and limitations still exist. They concern such aspects of life as law, transport, information, medicine, economy, and access to public buildings.

Both domestic and foreign authors of numerous research works, pay attention to the medical needs of the disabled and the existence of various limitations connected with the access to medical and dental services [1-3].

Statistics shows a constant increase in the number of disabled people, including mentally handicapped ones, who suffer from advanced, acute, and chronic pathological disorders concerning dentition and periodontium [4]. This group of patients requires a systematic dental care.

Adult patients with various disabilities constitute a very serious medical problem in both general and specialist medical care, including dentistry. Many difficulties are caused by the specificity of the general diseases. Mostly, these patients are absorbingly "difficult", time-consuming, and require patience, therefore dentists are reluctant to treat them.

The knowledge of disabilities and specific diseases make it necessary to treat these people in special conditions and by specially trained medical personnel. Dental treatment under general anesthesia is the most recommended for this group of patients. 


\section{AIM}

The aim of this study was to analyze the structure of a group of adult disabled patients treated dentally under general anesthesia.

\section{MATERIAL AND METHODS}

The study was conducted among 147 disabled people, 61 females and 86 males aged 18-56 (the average age 26.69) from the Lubelskie Voivodeship, qualified for dental treatment under general anesthesia .

The survey was based on interviews with the family members or social workers.

The questionnaire included the information concerning general diseases, age, gender, place of residence and the kind of care (family or social welfare institutions). Special attention was paid to the previous dental treatment performed in outpatient clinics or under general anesthesia. Responses were marked in check boxes. Laboratory tests were recommended before the dental treatment under general anesthesia. When possible, the X-ray examination was performed.

The examined people were divided into five groups according to the diagnosis of medical specialists: mentally handicapped, cerebral palsy, autism spectrum disorders, epilepsy and other diseases (cardiovascular disease, neuroblastoma, respiratory diseases, Hodgkin's disease, multiple sclerosis).

The analysis of the examined group according to gender, place of residence, age, diagnosed general diseases and the kind of care was performed. Previous dental procedures performed in outpatient clinics or during subsequent dental treatment under general anesthesia were also analyzed.

\section{RESULTS}

The results are presented on Figures 1-7.

Classification of patients according to gender, place of residence, age, diagnosed general diseases and the kind of care is shown on Figures 1-5.

The study involved a group of 147 people, including $58.50 \%$ males and $41.50 \%$ females (Figure 1 ).

Patients from a big city accounted for $40.14 \%, 23.13 \%$ of patients were from a small town, and $36.73 \%$ of the people came from the village (Figure2).

The average age of the patients was $26.69 \pm 6.41$ years (ranged from 18 to 56 ). Patients aged 18 constituted 14.29\%, those aged 19-20accounted for $14.29 \%, 21-25$ year-olds constituted $36.73 \%$, whereas $17.69 \%$ patients were at the age 26-30 and $17.00 \%$ above 30 years (Figure 3 ).

The largest group of patients were people with mental disabilities (54.43\%) while $22.45 \%$ had cerebral palsy, $6.80 \%$ were autistic, $9.52 \%$ suffered from epilepsy and $6.80 \%-$ with other diseases (diseases of the cardiovascular system, neuroblastoma, respiratory diseases, Hodgkin's disease, multiple sclerosis) (Figure4).

Most people $(87.76 \%)$ lived with their family, while $12.24 \%$ were the residents of social welfare institutions (Figure 5).

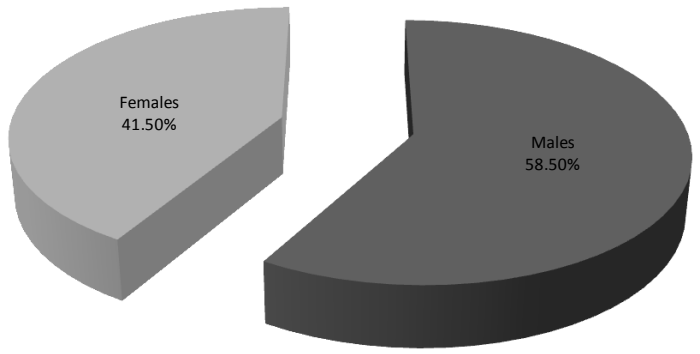

FIGURE 1. Percentage of examined patients according to gender.

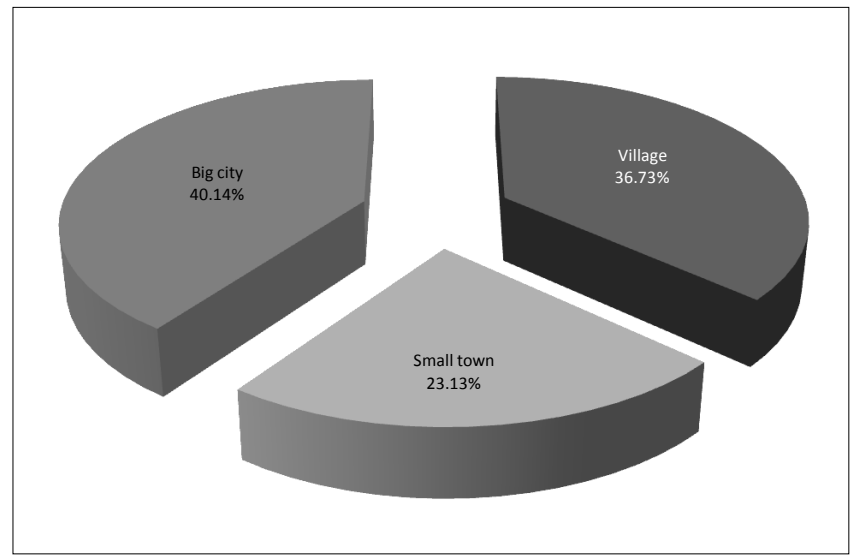

FIGURE 2. Percentage of examined patients according to place of residence.

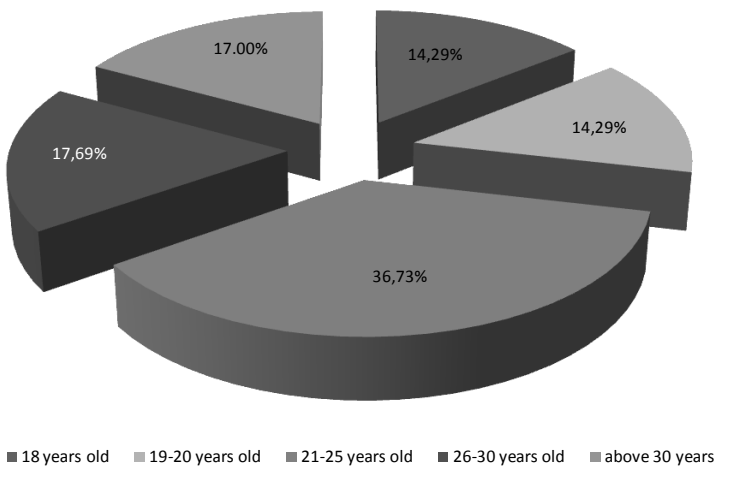

FIGURE 3. Percentage of examined patients according to age.

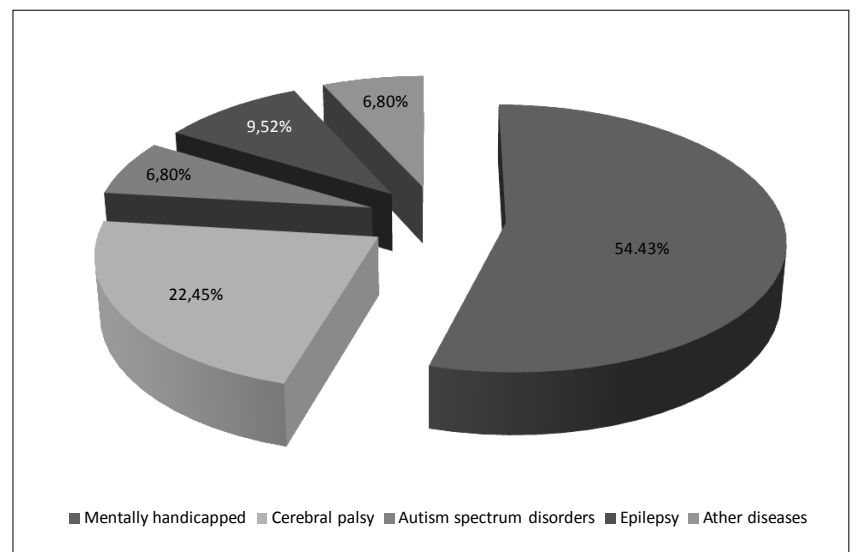

FIGURE 4. Percentage of examined patients according to diagnosed general diseases. 


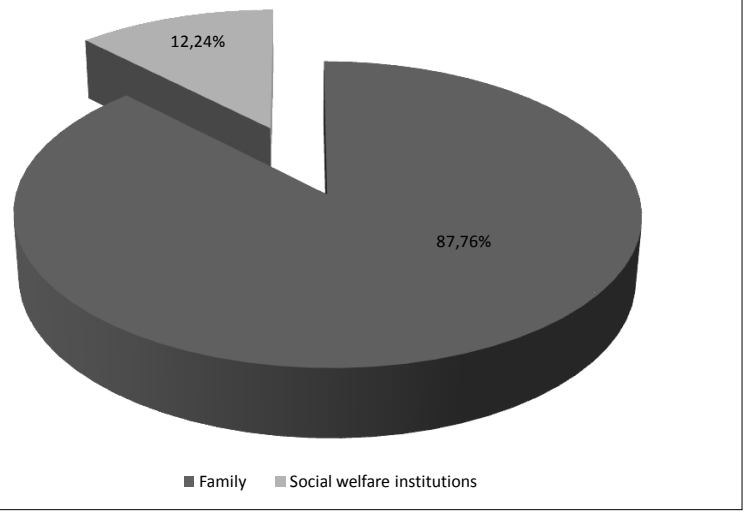

FIGURE 5. Percentage of examined patients according to the kind of care.

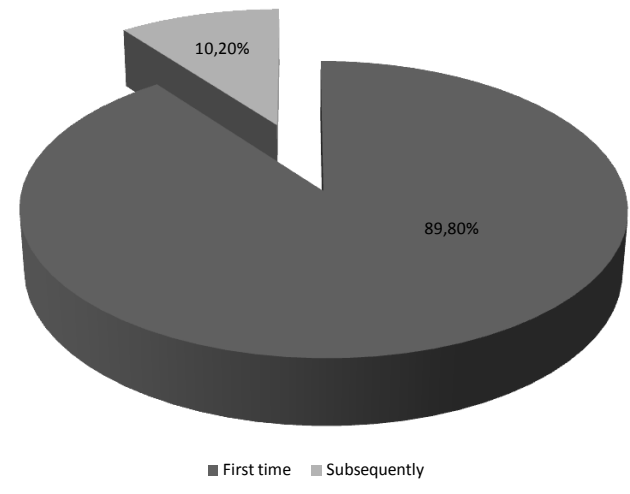

FIGURE 6. The percentage of patients with regard to the first and subsequent dental treatment under general anesthesia.

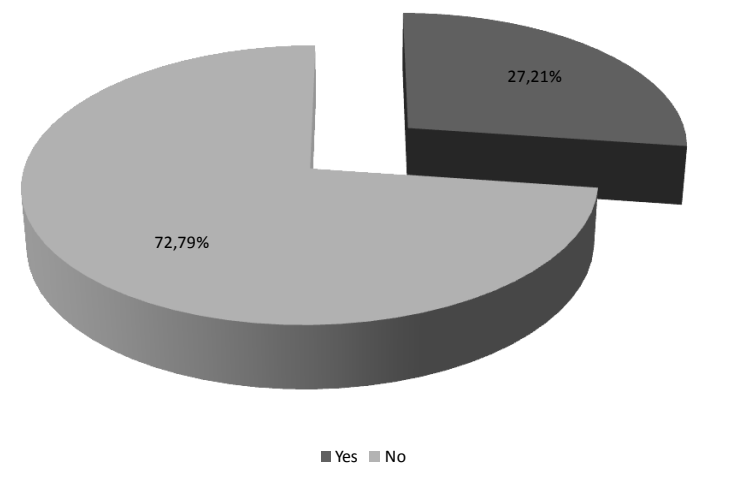

FIGURE 7. Percentage of patients who underwent outpatient treatment prior to dental treatment under general anesthesia.

The percentage of patients treated dentally for the first time and subsequently under general anesthesia is shown on Figure 6.

The analysis of the data reveals that for $89.80 \%$ of patients, it was their first dental treatment under general anesthesia, and for $10.20 \%$, a subsequent one.

The percentage of patients who underwent dental outpatient procedures before dental treatment under general anesthesia is shown on Figure 7.

Studies have shown that early treatment in outpatient clinics was performed in only $27.21 \%$ of treated people, while $72.79 \%$ have never been treated in a dental surgery.

\section{DISCUSSION}

The population of disabled patients, including mental disabilities, is a serious social and health problem. Because of large therapeutic difficulties arising from mental and somatic disorders, these people are rarely dentally treated in outpatient clinics. Therefore, they are qualified for dental treatment under general anesthesia.

In the research, only $27.21 \%$ of patients were treated in outpatient clinics before any treatment under general anesthesia. The majority of research works presenting results of oral health in disabled patients, including mental disabilities, rely on studies that were conducted under outpatient conditions and also in situations where you could examine a large number of such people in institutions, special schools and kindergartens, in social welfare institutions, rehabilitation centers, and even Para-Olympic Games and sport events [5-8]

The patients were mostly recruited from psychiatric, neurological, oncology and internal diseases clinics.

They were qualified for dental treatment under general anesthesia with the following diagnosis: mental retardation $-54.43 \%$; cerebral palsy $-22.45 \%$; epilepsy $-9.52 \%$; autism $-6.80 \%$ and others $-6.80 \%$ (cardio-vascular, neuroblastoma, respiratory diseases, Hodgkin's disease, multiple sclerosis). There are no clearly defined indications to perform dental procedures under general anesthesia. Similarly classified groups of patients according to general diseases were published by other authors [9-11].

The data show that dental treatment under general anesthesia is performed more often in the group of men $(58.50 \%)$ than women $(41.50 \%)$. Similar observations can be found in publications of Manowska et al. [4] and Wąsek et al. [12].

As a result of statistical analysis, it was found out that the mean age of patients was $26.69 \pm 6.41$ years (range $18-56$ years). Few studies concern the adult population with disabilities, including intellectual disabilities in the specified age group [13-16] .

In the present study, a large percentage $(36.73 \%)$ of the patients who were treated under general anesthesia came from rural areas. Similar results were revealed in the studies performed in Lublin districts [10,13]. Studies conducted in the Lodz region show that adults with disabilities coming from rural areas were treated under general anesthesia at a much lower percentage - $14 \%$ [4].

The study shows that patients treated under general anesthesia were most often under the care of the family $(87.76 \%)$ and only $12.24 \%$ of them were residents of social welfare institutions. According to Manowska et al., the data obtained from a careful analyses of the histories of adult disabled patients dentally treated under general anesthesia in Lodz show that $67.2 \%$ of the patients lived with family and $32.8 \%$ were residents of social welfare institutions [4].

In the presentstudy, $89.80 \%$ of patients were treated dentally under general anesthesia for the first time whereas for only $10.20 \%$ it was a subsequent treatment. Similar results were published by Gereth et al. [17].

There is a scarce record concerning dental treatment under general anesthesia in adult patients with disabilities $[4,9,18,19]$. 
Michalowski [10] presents the results of research, which he also obtained during the treatment of disabled patients under general anesthesia. However, his study concerns the handicapped children and adolescents. In the available literature, most of the research relates to dental treatment under general anesthesia among handicapped children and adolescents [17,20-24].

The authors of numerous studies emphasize that dental treatment under general anesthesia is recommended most for disabled patients [9,17,19,20,24-27].

\section{CONCLUSIONS}

1. Mentally handicapped people were the largest group of patients treated dentally under general anesthesia.

2. Patients living in the urban areas and under the care of families were more often treated dentally under general anesthesia.

3. Because of the lack of cooperation between disabled patients and the dentist, the complete dental treatment under general anesthesia is the most effective therapy.

4. Adult disabled patients require special dental care.

\section{REFERENCES}

1. Borysewicz-Lewicka M, Gerrreth K. Opieka stomatologiczna nad pacjentem niepełnosprawnym intelektualnie - potrzeby i ograniczenia. Czas Stomatol. 2009;62(1):34-41.

2. All Agili DE, Roseman J, Pass MA, et al. Access to dental care in Alabama for children with special needs. Parents' perspective. J Am Dent Assoc. 2004;135(4):490-5.

3. Miller CE. Access to care for people with special needs: role of alternative providers and practice settings. J Calif Dent Assoc. 2005;33(9):71521.

4. Manowska B, Diechtiarow D, Arkuszewski P. Analiza problemów występujących w opiece stomatologicznej dorosłych pacjentów niepełnosprawnych umysłowo. Czas Stomatol. 2008;61(6):420-7.

5. Borysewicz-Lewicka M, Wochna-SobańskaM, Mielnik-Błaszczak $\mathrm{M}$, et al. Ocena stomatologicznych zachowań prozdrowotnych dzieci i młodzieży niepełnosprawnej z wybranych województw Polski-badania socjomedyczne. Czas Stomatol. 2010;63(1):18-26.

6. Gerreth K, Borysewicz-Lewicka M. Ocena profilaktycznej opieki stomatologicznej u uczniów szkół specjalnych w badaniu klinicznym i socjomedycznym. Czas Stomatol. 2008;61(10):691-703.

7. Rao D, Amitha H, Munshi AK. Oral hygiene status of disabled children and adolescents attending special scools of South Canara, India. Hong Kong Dental J. 2005;2:107-13.

8. Reid BC, Chenette R, Macek MD. Prevalence and predictors of untreated caries and oral pain among Special Olympic athletes. Spec Care Dentist. 2003;23:139-42.

9. Cortinas-Saenz M, Martinez-Gomez L, Roncerno-Going M, et al. Results of major ambulatory oral surgery program using general inhalational anesthesia on disabled patients. Med Oral Patol Oral Cir Bucal. 2009;14(11):605-11.
10. Michałowski A. Ocena potrzeb leczniczych u dzieci i młodzieży z Makroregionu Lubelskiego poddanych leczeniu stomatologicznemu w znieczuleniu ogólnym. Praca doktorska. Lublin: Akademia Medyczna w Lublinie; 2004.

11. O Donnell D, Sheiham A, Wai YK. Dental findings in 4-, 14-, and 25to 35 -year-old Hong Kong residents with mental and physical disabilities. Spec Care Dentist. 2002;22(6):231-4.

12. Wąsek A, Wiśniwska J, Koziarz A, et al. Problemy stomatologiczne dzieci i młodzieży z niedorozwojem umysłowym w materiale własnym. Mag Stomatol. 2002;12:46-8.

13. Dobroczyńska-Krefta B. Ocena stanu jamy ustnej osób dorosłych niepełnosprawnych intelektualnie $i$ wpływ sprawowanej opieki na potrzeby stomatologiczne tej grupy chorych. Praca doktorska. Lublin: Uniwersytet Medyczny w Lublinie; 2010.

14. Pezzementi ML, Fisher MA. Oral health status of people with intellectual disabilities in the southeastern Unitet States. Jada. 2005;136:903-12.

15. Seirawan H, Schneiderman J, Greene V, Mulligan R. Intedisciplinary approach to oral health for persons with developmental disabilities. Spec Care Dentist. 2008;28(2):43-52.

16. Vazquez CR, Garcilan MR, Riaboo R, Bratos E. Prevalence of dental caries in an adult population with mental disabilities in Spain. Spec Care Dentist. 2002;22(2):65-9.

17. Gerreth K, Cieślińska K. Zabiegi stomatologiczne w znieczuleniu ogólnym u dzieci niepełnosprawnych. Fam Med Prim Care Rev. 2005;7(1):63-7.

18. Chałas R, Tarczydło B, Orłowski M, et al. Dental services done in general anesthesia among handicapped persons being patients of Department of Conservative Dentistry in Lublin. Pol J Environ Stud. 2006;15(6B):510-1.

19. Messieha Z, Chelva RA, Hoffman I, Hoffman W. Five year ouycomes study of dental rehabilitation conducted under general anesthesia for special needs patients. Anesth Prog. 2007;54:170-4.

20. Adamczyk Ł, Olczak-Kowalczyk D. Leczenie stomatologiczne w znieczuleniu ogólnym dzieci przewlekle chorych. Dent Med Probl. 2010;47(1):61-8.

21. Al.-Eheideb AA, Herman NG. Outcomes of dental procedures perfomed on children under general anesthesia. J Clin Pediatr Dent. 2003;27:1813.

22. Lee PY. Chou MT, Chen YL, et al. Comprehensive dental treatment under general anesthesia in healthy and disabled children. Chang Gung Med J. 2009;32(6):636-41.

23. Michałowski A, Mielnik-Błaszczak M. Trzyletnia analiza zabiegów stomatologicznych w znieczuleniu ogólnym w makroregionie lubelskim. Stomatol Współcz. 2005;(Suppl. 2):33-6.

24. O'Leary I, Kinirons M, Strwart C, et al. Levels of oral disease in a sample of children with disability;a study carried out prior to comprehensive dental treatment under general anaesthesia. Eur Arch Paediatr Dent. 2007;8(3):150-2.

25. Michałowski A, Mielnik-Błaszczak M, Skawińska A, Teleon-Przekora E. Zabiegi stomatologiczne w znieczuleniu ogólnym w materiale Katedry i Zakładu Stomatologii Wieku Rozwojowego Uniwersytetu Medycznego w Lublinie - obserwacja roczna. Mag Stomatol. 2009;9:70-2.

26. Nowak T, Janas A, Bialkowska-Głowacka J, Grzesiak-Janas G. Leczenie chirurgiczne pacjentów z niedorozwojem umysłowym oraz ze wskazań psychicznych i neurologicznych w znieczuleniu ogólnym krótkotrwałym. Poradnik Stomatol. 2009;1:15-7.

27. Tsai CL, Tsai YL, Lin YT. A retrospective study of dental treatment under general anesthesia of children with or without a chronic ilness and/or a disability. Chang Gung Med J. 2006;29(4):412-8.

\section{Corresponding author}

Dr hab. n. med. Renata Chałas

7 Karmelicka Str., 20-081 Lublin, Poland

tel. 81 528-79-20

E-mail: basia.hendzel@gmail.com 